\title{
Keefektifan Model Predict-Observe-Explain terhadap Kemampuan Pemahaman Konsep pada Mata Pelajaran IPA
}

\author{
Marisa Rizqi Astuti', Joko Sulianto² \& Veryliana Purnamasari ${ }^{3}$ \\ 1,2,3PGSD FIP Universitas PGRI Semarang \\ 1,2,3 Jln. Sidodadi Timur Nomor 24, Karangtempel, Semarang Timur, Semarang \\ 'Email: marisarizai12@gmail.com \\ 2Email: sulianto.jo@gmail.com \\ 3Email: verylianapurnamasari@gmail.com
}

\begin{tabular}{|c|c|}
\hline ABSTRACT & ABSTRAK \\
\hline $\begin{array}{l}\text { The background that encourages this research is } \\
\text { comprehending the concept of fifth grade } \\
\text { students in science subject very low. The } \\
\text { objective to be achieved in this research is to } \\
\text { know the differences in the ability of } \\
\text { comprehending the concept of science in the } \\
\text { fifth grade students of SDN } 5 \text { Telukwetan Jepara } \\
\text { between learning using POE and learning model } \\
\text { using conventional method. This research is an } \\
\text { experimental research belongs to quantitative } \\
\text { method. This research used True Experimental } \\
\text { design. The type of the design is taken Posttest- } \\
\text { Only Control Design. Based on the results of the } \\
\text { research data analysis capabilities using the } \\
\text { concept comprehension test two parties, } \\
\text { obtained by tcount }=3.5259 \text {, and } t_{\text {table }}=2.0154 \\
\text { with a significance level of } 5 \% \text { by dk }=\mathrm{n}_{1}+\mathrm{n}_{2}-2= \\
23 \text { + } 23 \text { - } 2=44 \text {. Based on the results of the } \\
\text { analysis, obtained tcount> table is } 3.5259>2.0154 \\
\text { then } \mathrm{H}_{\mathrm{o}} \text { rejected and } \mathrm{H}_{\mathrm{a}} \text { accepted. Thus, we can } \\
\text { conclude that there are differences in the ability } \\
\text { of science to the students comprehending the } \\
\text { concept of learning used POE and learning } \\
\text { model using conventional method. }\end{array}$ & 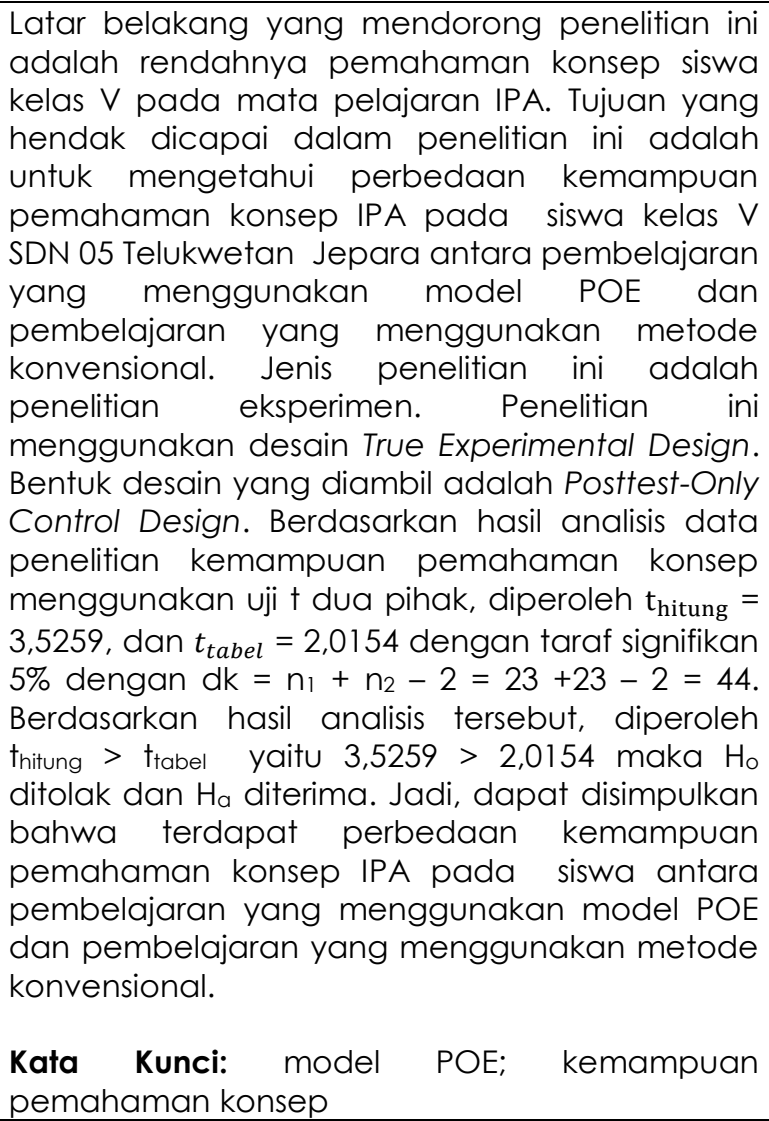 \\
\hline
\end{tabular}

How to Cite: Astuti, M., Sulianto, J., \& Purnamasari, V. (2017). Keefektifan Model Predict-Observe-Explain terhadap Kemampuan Pemahaman Konsep pada Mata Pelajaran IPA. Mimbar Sekolah Dasar, 4(3), $235-244$. http://doi.org/10.17509/mimbar-sd.v4i3.7876.

\section{PENDAHULUAN IImU Pengetahuan Alam}

(IPA) merupakan ilmu yang mempelajari tentang peristiwa atau gejala-gejala alam, dan mempelajari kehidupan alam sekitarnya (Servitri, 2017, p. 1). Winaputra (Samatowa, 2010, p. 3) menyebutkan bahwa IPA membahas tentang gejalagejala alam yang disusun secara sistematis yang didasarkan pada hasil percobaan dan pengamatan yang dilakukan oleh manusia. Atmojo (2015, p. 130) mengatakan, bahwa dalam 
Marisa Rizqi Astuti, Joko Sulianto \& Veryliana Purnamasari, Keefektifan Model Predict-Observe-Explain...

pembelajaran IPA, diperlukan keterampilan proses dari siswa untuk menemukan sejumlah konsep-konsep yang dipelajari. Bahkan, saat ini pengajaran IPA di sekolah tidak hanya mementingkan penguasaan terhadap fakta dan konsep, tetapi yang lebih penting adalah siswa memahami tentang proses bagaimana fakta dan konsep tersebut ditemukan yaitu dengan melalui observasi dan eksperimen. Melalui observasi dan eksperimen, siswa dituntut untuk aktif dan terlibat langsung dalam kegiatan pembelajaran, sehingga siswa dapat lebih memahami konsep-konsep IPA dan dapat mengingatnya lebih lama dibandingkan dengan pembelajaran yang menggunakan metode konvensional. Menurut Eliyani (2014, p. 2), mata pelajaran IPA lebih menekankan pada pemahaman konsep belajar sambil melakukan (learning by doing). Learning by doing adalah metode belajar yang dilakukan dengan cara berbuat atau memparaktekkan.

Proses pembelajaran di kelas sangat menentukan kemampuan pemahaman konsep siswa. Menurut Undang-Undang No. 20 Tahun 2003 tentang Sistem Pendidikan Nasional Bab 1 Pasal 1 Ayat 20 menyatakan bahwa "pembelajaran adalah proses interaksi antar siswa, antar siswa dengan pendidik dan sumber belajar pada suatu lingkungan belajar". Pembelajaran dapat berjalan dengan baik jika terjadi interaksi antara guru, siswa dan sumber belajar. Hal tersebut termasuk ke dalam pembelajaran aktif. Pembelajaran aktif merupakan metode pengajaran yang melibatkan siswa secara aktif dalam proses pembelajaran. Oleh karena itu, dengan menerapkan pembelajaran aktif dapat meningkatkan kemampuan pemahaman konsep IPA.

Guru dalam proses pembelajaran berperan penting dalam mencapai tujuan pembelajaran. Bahkan Samsudin (2014, p. 70) menegaskan bahwa guru merupakan pihak yang paling disorot dalam capaian belajar siswa. Peran guru dalam pembelajaran aktif adalah sebagai fasilitator yaitu guru yang dapat membawa siswa untuk berpartisipasi dalam pembelajaran yaitu memberikan kesempatan kepada siswa untuk mengemukakan gagasan maupun argumentasinya. Hal tersebut sesuai dengan teori konstruktivisme.

Konstruktivisme merupakan proses pembelajaran yang mengarahkan siswa untuk membangun dan mengkonstruksi pengetahuan yang baru dengan pengetahuan yang sudah dimilikinya, sehingga siswa dapat belajar secara bermakna. Pembelajaran bermakna yaitu pembelajaran yang tidak hanya menghafal konsep-konsep atau faktafakta, tetapi merupakan kegiatan yang menghubungkan konsep-konsep untuk menghasilkan pemahaman yang utuh, sehingga konsep yang dipelajari akan dipahami secara baik dan tidak mudah dilupakan. 
Proses pembelajaran IPA di sekolah dasar masih banyak yang menggunakan metode konvensional. Metode konvensional ini kurang efektif dalam meningkatkan pemahaman konsep siswa, karena kurang melibatkan siswa secara aktif dalam kegiatan pembelajaran dan metode ini masih berpusat pada guru. Berdasarkan data nilai UTS siswa kelas $V$ semester 1 mata pelajaran IImu Pengetahuan Alam (IPA), dapat diketahui bahwa siswa kelas $\vee$ masih belum mencapai Kriteria Ketuntasan Minimum (KKM) yang ditentukan oleh sekolah yaitu 65. Data dari siswa kelas VA hanya $43 \%$ siswa yang dapat memenuhi KKM, sedangkan siswa kelas VB yang memenuhi KKM hanya $48 \%$ siswa. Sehingga, dapat disimpulkan bahwa pemahaman konsep pada mata pelajaran IPA rendah.

Pemahaman konsep siswa akan meningkat jika dalam proses pembelajaran IPA menggunakan model pembelajaran yang tepat. Model pembelajaran yang dapat diterapkan dalam pembelajaran IPA adalah model POE (Predict-Observe-Explain). Model pembelajaran POE adalah model pembelajaran yang melibatkan siswa secara langsung dalam proses pembelajaran dengan cara melakukan eksperimen, sehingga pengetahuan yang diperoleh menjadi lebih bermakna. Model pembelajaran POE adalah model pembelajaran yang melibatkan siswa dalam memprediksi suatu fenomena atau kejadian, melakukan observasi melalui demonstrasi atau eksperimen, dan akhirnya menjelaskan hasil eksperimen mereka dan prediksi mereka sebelumnya. Salah satu manfaat model pembelajaran POE adalah memotivasi siswa agar berkeinginan untuk melakukan eksperimen sehingga siswa lebih memahami konsep. Keunggulan dari model pembelajaran Predict-Observe-Explain (POE) ini dibandingkan dengan metode pembelajaran konvensional adalah keaktifan siswa dalam mencari tahu informasi dan interaksi yang baik antara siswa dengan siswa maupun siswa dengan guru.

Berdasarkan latar belakang tersebut, maka peneliti tertarik untuk melakukan penelitian dengan tujuan untuk mengetahui perbedaan kemampuan pemahaman konsep IPA pada siswa kelas $\checkmark$ SDN 05 Telukwetan Jepara antara pembelajaran yang menggunakan model POE dan pembelajaran yang menggunakan metode konvensional.

\section{METODE}

Jenis penelitian ini adalah penelitian eksperimen dengan menggunakan True Experimental Design dengan bentuk Posttest Only Control Design. Desain ini menggunakan dua kelas yaitu kelas eksperimen dan kelas kontrol. Kelas eksperimen adalah kelas yang diberi perlakuan berupa pembelajaran dengan menggunakan model POE (PredictObserve-Explaine), sedangkan kelas 
Marisa Rizqi Astuti, Joko Sulianto \& Veryliana Purnamasari, Keefektifan Model Predict-Observe-Explain...

kontrol adalah kelas yang tidak diberikan perlakuan.

Penelitian ini dilaksanakan di SDN 05 Telukwetan, Kecamatan Welahan, Kabupaten Jepara. Kegiatan penelitian ini dilaksanakan pada kelas $\mathrm{V}$ semester 2 Tahun Pelajaran 2016/2017.

Populasi dalam penelitin ini adalah seluruh siswa kelas $V$, yang terbagi menjadi dua kelas yaitu kelas VA dan VB. Teknik pemilihan sampel dalam penelitian menggunakan teknik non probability sampling dengan jenis sampling jenuh. Menurut Sugiono (2014, p. 85) sampling jenuh adalah "teknik penentuan sampel bila semua anggota populasi digunakan sebagai sampel".

Teknik pengumpulan data dalam penelitian ini menggunakan teknik tes. Teknik tes digunakan untuk mengetahui kemampuan pemahaman konsep siswa pada materi sifat-sifat cahaya. Peneliti memberikan tes kepada kedua kelas, yaitu kelas kontrol dan kelas eksperimen berupa soal posttest berbentuk pilihan ganda berjumlah 22 butir soal. Data dari penelitian ini berupa data akhir yaitu hasil posttest dari kelas eksperimen dan kelas kontrol. Sedangkan data awal diperoleh dari nilai UTS IPA kelas $V$ pada semester 1. Data awal digunakan untuk mengetahui apakah terdapat kesamaan kemampuan awal siswa.

Teknik analisis data dalam penelitian ini dilakukan dengan dua tahap yaitu teknik analisis data awal dan akhir. Uji prasyaratan analisis data awal menggunakan menggunakan uji normalitas dengan uji liliefors, uji homogenitas dengan uji $F$, dan uji matching group. Sedangkan Uji prasyaratan analisis data akhir sama dengan menggunakan menggunakan uji normalitas, uji homogenitas dan uji hipotesis yang menggunakan uji $\dagger$ dua pihak. Dalam proses analisis data menggunakan bantuan Microsoft Office Excel 2007.

\section{HASIL}

Berdasarkan Hasil penelitian berupa hasil postest kemampuan pemahaman konsep, dapat dideskripsikan bahwa terdapat perbedaan kemampuan pemahaman konsep IPA siswa kelas $V$ antara kelas yang diberikan perlakuan menggunakan model pembelajaran POE dengan kelas yang menggunakan metode pembelajaran konvensional. Hal ini terlihat dari hasil analisis data nilai postest kemampuan pemahaman konsep siswa. Siswa kelas VA di kelas eksperimen lebih unggul dibandingkan dengan kelas VB di kelas kontrol. Daftar nilai kemampuan pemahaman konsep kelas kontrol dan kelas eksperimen dapat dilihat pada tabel 1.

Berdasarkan tabel 1, dapat dilihat bahwa rata-rata nilai kemampuan pemahaman konsep kelas eksperimen lebih tinggi dari kelas kontrol. Kelas eksperimen 
Tabel 1. Daftar Nilai Kemampuan Pemahaman Konsep Kelas Eksperimen dan Kelas Kontrol

\begin{tabular}{ccc}
\hline \multirow{2}{*}{ Keterangan } & \multicolumn{2}{c}{ Nilai Posttest } \\
\cline { 2 - 3 } & Kelas Eksperimen & Kelas Kontrol \\
\hline Nilai tertinggi & 95,4 & 90,9 \\
Nilai terendah & 50 & 40,9 \\
Rata-rata & 80,43 & 67,58 \\
Siswa tuntas & 21 & 13 \\
Siswa tidak tuntas & 2 & 10 \\
Persentase ketuntasan & $91,3 \%$ & $56,5 \%$ \\
\hline
\end{tabular}

Sebelum melakukan uji hipotesis terlebih dahulu dilakukan uji prasyaratan analisis. Uji persyaratan analisis data awal yaitu menggunakan uji normalitas, uji homogenitas dan uji matching group. Uji normalitas dilakukan pada dua kelompok data, meliputi data kelompok eksperimen dan data kelompok kontrol. Uji normalitas ini digunakan untuk mengetahui apakah data yang digunakan merupakan data yang berdistribusi normal atau tidak. Uji normalitas dilakukan dengan menggunakan uji Liliefors pada taraf signifikansi $5 \%$.

Berdasarkan uji Liliefors data awal pada kelas eksperimen diperoleh Lhitung $=0,1608$, dengan $n=23$ dan taraf signifikan $5 \%$ diperoleh Ltabel $=0,1798$, sehingga Lhitung $<$ Ltabel yaitu $0,1608<0,1798$ maka $\mathrm{H}_{0}$ diterima. Sehingga dapat disimpulkan bahwa data nilai UTS siswa kelas eksperimen, berasal dari populasi yang berdistribusi normal. Begitu juga dengan kelas kontrol diperoleh Lhitung $=0,1436$, dengan $n=23$ dan taraf signifikan 5\% diperoleh Ltabel $=0,1798$, sehingga Lhitung $<$
Ltabel yaitu $0,1436<0,1798$ maka $\mathrm{H}_{0}$ diterima.

Uji homogenitas yang digunakan dalam penelitian ini menggunakan uji F. Uji homogenitas digunakan untuk menguji kesamaan varians dari dua kelompok yang berdistribusi normal. Berdasarkan perhitungan uji $\mathrm{F}$ dari data awal kelas eksperimen dan kelas kontrol, diperoleh varians kelas eksperimen $=147,87$ dan varians kelas kontrol $=75,57$ maka diperoleh F hitung $=1,957$. Berdasarkan daftar tabel diperoleh nilai $F_{\text {tabel }}=2,05$ dengan $\mathrm{dk}$ pembilang 22 , dk penyebut 22 , dan taraf signifikan 5\%. Dari perhitungan tersebut maka Fhitung < Ftabel yaitu 1,957 < 2,05 sehingga $\mathrm{H}_{0}$ diterima. Sehingga dapat disimpulka bahwa kedua kelompok tersebut mempunyai varians yang sama atau homogen.

Uji matching group ini digunakan untuk mengetahui apakah nilai rata-rata UTS IPA pada kelas eksperimen dan kelas kontrol memiliki perbedaan atau tidak. Uji matching group pada penelitian ini ada tiga tahapan, pertama mencari mean 
Marisa Rizqi Astuti, Joko Sulianto \& Veryliana Purnamasari, Keefektifan Model Predict-Observe-Explain...

dari masing-masing kelas, kemudian mencari standar deviasi dari masingmasing kelas, selanjutnya mencari perbedaan dengan menggunakan rumus uji † dua sampel.

Berdasarkan hasil analisis tersebut, dapat diketahui bahwa pada kelas diperoleh mean yaitu 63,35 dan standar deviasi (SD) 12,16. Sedangkan kelas kontrol diperoleh mean sebesar 64,74 dan standar deviasi 8,69. Kemudian dianalisis dengan uji $\dagger$ matching group, rumus yang digunakan adalah separated varians, diperoleh thitung $=-0,4464$ dengan $\mathrm{dk}=\mathrm{n} 1+\mathrm{n} 2-2=23$ $+23-2=44$ dan taraf signifikan $5 \%$, sehingga diperoleh tabel $=2,0154$. Berdasarkan hasil analisis tersebut, diperoleh $t_{\text {hitung }}<t_{\text {tabel }}$ yaitu $-0,4464<$ 2,0154 maka $\mathrm{H}_{0}$ diterima. Sehingga dapat disimpulkan bahwa tidak ada perbedaan nilai rata-rata UTS kelas eksperimen dan kelas kontrol.

Uji persyaratan analalisi data akhir menggunakan uji normalitas dan uji homogenitas dan uji hipotesis. Berdasarkan uji Liliefors pada kelas eksperimen diperoleh Lhitung $=0,112$, dengan $n=23$ dan taraf signifikan 5\% diperoleh Ltabel $=0,1798$, sehingga Lhitung $<$ Ltabel yaitu $0,112<0,1798$ maka Ho diterima. Sehingga dapat disimpulkan bahwa data hasil posttest kemampuan pemahaman konsep kelas eksperimen, berasal dari populasi yang berdistribusi normal.
Begitu juga dengan uji Liliefors pada kelas kontrol diperoleh Lhitung $=0,0873$, dengan $n$ = 23 dan taraf signifikan 5\% diperoleh Ltabel $=0,1798$, sehingga Lhitung $<$ Ltabel yaitu 0,0873 $<0,1798$ maka $H_{0}$ diterima. Sehingga dapat disimpulkan bahwa data nilai posttest kemampuan pemahaman konsep kelas kontrol, berasal dari populasi yang berdistribusi normal.

Uji homogenitas yang digunakan dalam penelitian ini menggunakan uji $F$. Berdasarkan perhitungan uji $\mathrm{F}$ dari data akhir kelas eksperimen dan kelas kontrol, diperoleh varians kelas eksperimen = 150,8994 dan varians kelas kontrol = 154,5501 maka diperoleh Fhitung $=1,0242$. Berdasarkan daftar tabel diperoleh nilai $F_{\text {tabel }}=2,05$ dengan $\mathrm{dk}$ pembilang $22, \mathrm{dk}$ penyebut 22 , dan taraf signifikan $5 \%$. Dari perhitungan tersebut maka Fhitung $<$ Ftabel yaitu $1,0242<2,05$ sehingga $\mathrm{H}_{0}$ diterima. Sehingga dapat disimpulkan bahwa kedua kelompok tersebut mempunyai varians yang sama atau homogen.

Uji hipotesis dalam penelitian ini menggunakan Uji T dua pihak (two tail test). Uji $\dagger$ dua pihak digunakan untuk mengetahui apakah terdapat perbedaan kemampuan pemahaman konsep siswa antara pembelajaran dengan model POE (Predict-Observe-Explaine) dan metode konvensional. Pengujian hipotesis ini menggunakan rumus t-test. Rumus t-test yang dapat digunakan untuk menguji hipotesis adalah Separated Varians. 
Kriteria pengujiannya adalah $\mathrm{H}_{0}$ diterima jika Ho $=t_{\text {hitung }} \leq t_{\text {tabel }}$ dan $\mathrm{Ha}_{\text {a diterima jika, }}$ $\mathrm{Ha}=t_{\text {hitung }} \geq t_{\text {tabel }}$. Dengan nilai $t_{\text {tabel }}$ taraf signifikan $5 \%$ dan derajat kebebasan $\mathrm{dk}=\mathrm{n}_{1}+\mathrm{n}_{2}-2$

Tabel 2. Uji T Dua Pihak

\begin{tabular}{cccc}
\hline $\mathbf{N}$ & thitung & t $_{\text {tabel }}$ & Kesimpulan \\
\hline 23 & 3,5259 & 2,0154 & Terdapat perbedaan \\
\hline
\end{tabular}

Berdasarkan hasil perhitungan uji $\mathrm{T}$ dua pihak dari hasil posttess kemampuan pemahaman konsep kelas eksperimen dan kelas kontrol dengan menggunakan rumus Separated Varians, diperoleh $t_{\text {hitung }}$ $=3,5259$, dan diperoleh $t_{\text {tabel }}=2,0154$ dengan taraf signifikan $5 \%$ dengan $\mathrm{dk}=\mathrm{n} 1$ $+n 2-2=23+23-2=44$. Berdasarkan hasil analisis tersebut, diperoleh thitung $>t_{\text {tabel }}$ yaitu 3,5259 > 2,0154 maka $\mathrm{H}_{0}$ ditolak dan $\mathrm{Ha}_{\mathrm{a}}$ diterima. Jadi, kesimpulan yang diperoleh dari uji T dua pihak dari data akhir kelas eksperimen dan kelas kontrol adalah terdapat perbedaan kemampuan pemahaman konsep IPA pada siswa kelas $\checkmark$ SDN 05 Telukwetan Jepara antara pembelajaran yang menggunakan model POE dan pembelajaran yang menggunakan metode konvensional.

\section{PEMBAHASAN}

Pada kelas eksperimen pembelajaran dilaksanakan dengan menggunakan model POE (Predict-Observe-Explaine). Menurut Suyono \& Hariyanto (2014, p. 4142) Pembelajaran dengan model POE terdiri dari 3 tahapan, yaitu memprediksi, mengamati dan menjelaskan.
Tahap pertama yaitu memprediksi, sebelum siswa memprediksi terlebih dulu dibentuk kelompok. Guru membagi siswa menjadi 5 kelompok secara acak. Setiap kelompok memiliki kemampuan yang heterogen. Guru meminta setiap kelompok mengambil LKPD beserta alat dan bahan untuk melakukan percobaan. Setelah itu, guru menghadapkan siswa dengan alat dan bahan percobaan yang akan dilakukan, kemudian guru menjelaskan apa saja yang harus dilakukan terkait peralatan tersebut. Siswa kemudian membuat suatu prediksi tentang apa yang akan terjadi dengan alat dan bahan tersebut. Siswa melakukan prediksi dengan menganalisis pertanyaan yang terangkum dalam LKPD. Pertanyaan tersebut terkait dengan apa yang akan terjadi pada percobaan tersebut. Siswa terlihat sangat antusias dalam memprediksi apa yang akan terjadi, hal tersebut dibuktikan dengan siswa bertanya kepada guru tentang pertanyaan yang kurang dimengerti.

Tahap kedua setelah memprediksi yaitu mengamati. Setelah memprediksi siswa diarahkan oleh guru untuk melakukan percobaan berdasarkan petujuk yang 
Marisa Rizqi Astuti, Joko Sulianto \& Veryliana Purnamasari, Keefektifan Model Predict-Observe-Explain...

tertera dalam LKPD. Siswa mengamati percobaan dan menganalisis hasil percobaan kemudian mendiskusikannya. Pada tahap ini, siswa terlibat aktif dalam pembelajaran, hal tersebut terlihat dari semua anggota mengikuti langkahlangkah percobaan, siswa secara aktif bertanya kepada guru apabila menemui kesulitan, berdiskusi dengan anggota kelompok, serta menganalisis hasil pengamatan berdasarkan percobaan yang telah dilakukan.

Tahap selanjutnya yaitu menjelaskan (explaine). Pada tahap ini masing-masing kelompok menjelaskan hasil diskusinya yang berupa hasil percobaan dan mencocokkan dengan prediksi yang sudah dibuat sebelumnya di hadapan kelompok lain. Sedangkan kelompok lain memberikan tanggapan kepada kelompok yang sedang mempresentasikan. Setiap kelompok sangat antusias untuk memberikan tanggapan terhadap kelompok yang maju. Pada tahap ini siswa dapat membangun pengetahuannya sendiri yaitu dari prediksi dan hasil pengamatan, sehingga menghasilkan materi yang dipahami oleh siswa. Hal tersebut sesuai dengan bentuk kondisi belajar yang sesuai dengan teori konstruktivisme. Menurut Taniredja (2014, p. 13) ada beberapa bentuk kondisi belajar yang sesuai dengan teori konstruktivisme antara lain: diskusi yang memberikan kesempatan agar semua siswa mau mengungkapkan gagasannya, menguji hasil penelitian sederhana, demonstrasi atau percobaan dan peragaan prosedur ilmiah, dan kegiatan praktis lain yang memberi peluang kepada siswa untuk mempertajam gagasannya.

Kondisi belajar dalam teori konstruktivisme tersebut membantu siswa untuk lebih memahami materi yang diajarkan. Hal tersebut dibuktikan dengan nilai rata-rata kemampuan pemahaman konsep siswa yang tinggi. Dari hasil posttest diperoleh rata-rata nilai kelas eksperimen sebesar 80,43 , terdapat 21 siswa tuntas dan 2 siswa tidak tuntas. Dengan presentase ketuntasan sebesar 91,3\%.

Berbeda dengan kelas eksperimen, pembelajaran IPA pada kelas kontrol menggunakan metode konvensional. Pada pembelajaran ini, terlihat siswa kurang aktif dalam pembelajaran. Siswa hanya bisa mendengarkan penjelasan dari guru, dan mencatat materi yang ditulis guru di papan tulis. Pada saat siswa diberikan pertanyaan tentang materi yang diajarkan, siswa kurang aktif dalam menjawab pertanyaan, hanya 2 atau 3 siswa yang menjawab. Pembelajaran di kelas kontrol ini hanya terpusat pada guru, sehingga mengakibatkan nilai posttest kemampuan pemahaman konsep rendah daripada kelas eksperimen yang menggunakan model POE. Dari hasil posttest diperoleh rata-rata nilai kelas kontrol sebesar 67,58, terdapat 13 siswa tuntas dan 10 siswa tidak tuntas. Dengan presentase ketuntasan sebesar $56,5 \%$. 
Berdasarkan pengujian hipotesis yang dianalisis dengan uji T dua pihak, diperoleh $t_{\text {hitung }}=3,5259$, dan diperoleh $t_{\text {tabel }}=$ 2,0154 dengan taraf signifikan $5 \%$ dengan $\mathrm{dk}=\mathrm{n} 1+\mathrm{n} 2-2=23+23-2=44$. Berdasarkan hasil analisis tersebut, diperoleh thitung $>$ tabel yaitu 3,5259 $>2,0154$ maka $\mathrm{H}_{0}$ ditolak dan $\mathrm{H}_{\mathrm{a}}$ diterima. Jadi, kesimpulan yang diperoleh yaitu terdapat perbedaan kemampuan pemahaman konsep IPA pada siswa kelas V SDN 05 Telukwetan Jepara antara pembelajaran yang menggunakan model POE dan pembelajaran yang menggunakan metode konvensional.

Berdasarkan hasil hipotesis tersebut, membuktikan bahwa pembelajaran dengan menggunakan model POE (Predict-Observe-Explaine) ini efektif digunakan dalam proses pembelajaran IPA di SDN 05 Telukwetan, karena dalam pembelajaran $\mathrm{POE}$, siswa terlibat langsung dalam kegiatan pembelajaran, dan antusias dalam memprediksi, mengamati dan menjelaskan (mempresentasikan) hasil percobaan, sehingga mendorong keaktifan siswa selama proses pembelajaran berlangsung.

Hal tersebut sesuai dengan pendapat yang dikemukakan Sudiadnyani (2013, p. 3) bahwa keunggulan dari model pembelajaran Predict-Observe-Explain (POE) ini dibandingkan dengan metode pembelajaran konvensional adalah keaktifan siswa dalam menggali informasi, dan interaksi yang baik antar siswa maupun dengan guru dalam proses pembelajaran. Hal tersebut dibuktikkan dengan persentase ketuntasan kelas eksperimen lebih tinggi daripada kelas kontrol. Kelas eksperimen yang dikenai perlakuan dengan menggunakan model POE persentase ketuntasannya mencapai $91,3 \%$. Sedangkan kelas kontrol yang tidak dikenai perlakuan, persentase ketuntasannya sebesar 56,5\%. Dari penelitian yang sudah dilakukan diperoleh hasil akhir bahwa kemampuan pemahaman konsep siswa pada kelas eksperimen yang diberi perlakuan dan kelas kontrol yang tidak diberi perlakuan terdapat perbedaan, dimana pada ratarata nilai kemampuan pemahaman konsep siswa kelas eksperimen lebih tinggi dibanding kelas kontrol. Rata-rata nilai kelas eksperimen sebesar 80,43 sedangkan kelas kontrol sebesar 67,58. Jadi, secara keseluruhan model pembelajaran PredictObserve-Explain (POE) ini dapat meningkatkan pemahaman konsep siswa pada mata pelajaran IPA, karena dengan menggunakan model ini siswa dapat lebih aktif, interaksi antar siswa dan guru menjadi lebih baik dan dapat belajar secara bermakna sehingga materi yang dijarkan tetap diingat dan tidak mudah dilupakan.

\section{SIMPULAN}

Berdasarkan hasil penelitan, maka diperoleh kesimpulan bahwa terdapat perbedaan kemampuan pemahaman konsep IPA pada siswa kelas $V$ SDN 05 Telukwetan Jepara antara pembelajaran 
Marisa Rizqi Astuti, Joko Sulianto \& Veryliana Purnamasari, Keefektifan Model Predict-Observe-Explain...

yang menggunakan model POE dan pembelajaran yang menggunakan metode konvensional. Hal tersebut dibuktikan dengan $t_{\text {hitung }}>t_{\text {tabel }}$ pada uji $T$ dua pihak. Pada uji T dua pihak, diperoleh $t_{\text {hitung }}=3,5259$, dan diperoleh $t_{\text {tabel }}=2,0154$ dengan taraf signifikan $5 \%$ dengan $\mathrm{dk}=\mathrm{nl}$ $+n 2-2=23+23-2=44$. Berdasarkan hasil analisis tersebut, diperoleh thitung $>t_{\text {tabel }}$ yaitu $3,5259>2,0154$, maka $\mathrm{H}_{0}$ ditolak dan $\mathrm{Ha}_{\mathrm{a}}$ diterima. Jadi, kesimpulan yang diperoleh dari uji T dua pihak dari data akhir kelas eksperimen dan kelas kontrol adalah terdapat perbedaan kemampuan pemahaman konsep IPA pada siswa kelas $\checkmark$ SDN 05 Telukwetan Jepara antara pembelajaran yang menggunakan model POE dan pembelajaran yang menggunakan metode konvensional.

\section{REFERENSI}

Atmojo, I. (2015). PENGARUH PENGGUNAAN METODE DISCOVERY BERBASIS MEDIA REALITA TERHADAP HASIL BELAJAR MATAKULIAH KONSEP DASAR IPA 1. Mimbar Sekolah Dasar, 2(2), $\quad$ 130-139. doi:http://dx.doi.org/10.17509/mimbarsd.v2i2.1324.

Eliyani, Y. (2014). "Keefektifan Model Pembelajaran Tematik Terintegrasi Terhadap Kemampuan Pemahaman Konsep Siswa Kelas IV Sekolah Dasar Di Kelurahan Sragi Kabupaten
Pekalongan". Skripsi. Semarang: Universitas PGRI Semarang

Samatowa, U. (2011). Pembelajaran IPA di Sekolah Dasar. Jakarta: Indeks.

Samsudin, A. (2014). SUPERVISI AKADEMIK PEMBELAJARAN IPA MELALUI ICT BASED LESSON STUDY UNTUK MEMBANGUN LEARNING COMMUNITY GURU SD. Mimbar Sekolah Dasar, 1(1), 77-82. doi:http://dx.doi.org/10.17509/mimbarsd.vli1.867.

Servitri, M. (2017). PEMBELAJARAN MULTIMEDIA IPA DENGAN MODEL CONTEXTUAL TEACHING AND LEARNING UNTUK MENINGKATKAN HASIL BELAJAR SISWA. Mimbar Sekolah Dasar, 4(1), 1-8. doi:http://dx.doi.org/10.23819/mimbarsd.v4i1.6157.

Sisdiknas. (2003). Undang-Undang Sisdiknas (Sistem Pendidikan Nasional): UU RI No. 20 Th. 2003

Sudiadnyani, dkk. (2013). Pengaruh Model Pembelajaran Predict-Observe-Explain (POE) Terhadap Pemahaman KonsepIPA Siswa Kelas IV SD Di Kelurahan Banyuasri. Jurnal Sosial dan Pembangunan. Singaraja: Universitas Pendidikan Ganesha.

Sugiyono. (2014). Metode Penelitian Kuantitatif Kualitatif dan R\&D. Bandung: Alfabeta.

Suyono \& Hariyanto. (2014). Belajar dan Pembelajaran. Bandung: Remaja Rosdakarya.

Taniredja, dkk. (2014). Model-Model Pembelajaran Inovatif dan Efektif. Bandung: Alfabeta. 